\title{
PENINGKATAN KESADARAN METAKOGNITIF, KEPERCAYAAN DIRI DAN PEMAHAMAN LISTENING MELALUI STRATEGI PEMBELAJARAN SHADOWING
}

\author{
Laila Rochmawati \\ Aris Wijanarko \\ Politeknik Penerbangan Suarabaya \\ J1. Jemur Andayani I/73 Surabaya \\ lailaharun@gmail.com
}

\begin{abstract}
Abstrak
Penelitian ini bertujuan untuk mengetahui peningkatan pemahaman listening pada taruna poltekbang Surabaya tingkat 3 semester 5 dengan menggunakan strategi pembelajaran shadowing dan juga bagaimana hal itu dapat mempengaruhi kesadaran listening metakognitf, pemahaman listening dan kepercayaan diri listening mereka.. Untuk tujuan ini, 43 taruna tingkat 3 semester 5 kelas D.III LLU 8AB pada poltekbang Surabaya dengan rentang usia 19-23 tahun pada tingkat kemampuan menengah dalam pelajaran bahasa inggris melalui metode convenience sampling. Mereka secara acak dibagi menjadi dua kelompok eksperimen $(n=21)$ dan kontrol $(n=22)$. Kelompok experimen diberikan strategi shadowing pada kelas listening. Data diperoleh melalui tes pemahaman mendengar dan dua kuesioner terkait. Hasil mengungkapkan bahwa strategi pembelajaran shadowing memiliki dampak positif yang signifikan terhadap kinerja pendengaran peserta didik. Selanjutnya, korelasi antara stategi pembelajaran shadowing dan self-efficacy ditemukan cukup positif meski secara statistik tidak signifikan. Akhirnya, stategi pembelajaran shadowing ditemukan secara signifikan dan positif mempengaruhi frekuensi menggunakan strategi mendengarkan metakognitif. Temuan memiliki implikasi bagi pelajar dan guru bahasa.
\end{abstract}

Kata kunci : mendengarkan, kesadaran metakognitif, kepercayaan diri dan pemahaman listening, strategi pembelajaran shadowing.

\section{PENDAHULUAN}

Strategi pembelajaran shadowing dalam listening adalah, strategi pembelajaran yang digunakan dalam penelitian ini, diadaptasi dari Murphey (2001) "percakapan shadowing ", sebuah teknik pedagogis yang menjadi sebuah fenomena umum dalam wacana seseorang: kecenderungan untuk mengulang secara diam-diam atau keras terhadap pembicaraan lawan bicaranya atau perkataan pembicara sendiri. Tannen (2007), sering mengamati penggunaannya strategi pembelajaran shadowing spontan dalam percakapan, percaya bahwa Strategi pembelajaran shadowing merespons dasar dorongan manusia untuk meniru dan mengulangi. Shadowing juga telah dikenal sebagai teknik yang berguna untuk melatih menerjemahkan secara simultan (Kurz 1992, Sabatini 2000). Hasil dalam penelitian psikolinguistik adalah strategi ini digunakan untuk menilai kemampuan pengolahan bahasa, terutama mendengarkan dan membaca (Gray 1975, Marslen-Wilson 1975, Muchisky 1983). Sambil mendengarkan, pendengar menggunakan berbagai proses mental untuk memberi makna pada informasi yang mereka dengarkan. Proses mental inilah yang digunakan pendengar untuk mengerti bahasa inggris secara lisan pada umumnya dapat digambarkan sebagai strategi pemahaman mendengar (Coskun 2010). Oxford (1990) mengatakan bahwa "strategi sangat penting untuk pembelajaran bahasa, karena mereka merupakan alat untuk mengukur keterlibatan keaktifan dan selfdirected peserta didik, yang penting untuk pengembangan dan kompetensi komunikatif. Nunan (1999), berpendapat bahwa dibelakang setiap tugas belajar setidaknya terdapat satu strategi. Namun, peserta didik tidak mengetahui strategi di mana mereka terlibat.

Anderson (1999) menganggap strategi metakognitif sebagai strategi yang paling penting untuk mengembangkan kemampuan peserta didik. O'Malley dan Chamot berpendapat bahwa (1990) bahwa peserta didik yang belajar tanpa strategi ini tidak memiliki kemampuan untuk memantau dan mengatur perkembangan, kinerja, dan pembelajaran di masa depan. Di sisi lain, peserta didik yang menggunakan strategi metakognitif tersebut pelajar yang lebih mahir disbanding yang tidak menggnakan strategi metakognitif (Hauck, 2005). Pendapat yang sama dikemukakan oleh Yang 
(2009) yang mana kesadaran metakognitif dapat membantu meningkatkan kemampuan pendengar untuk menyelesaikan tugas listening lebih efektif. Di sisi lain, peserta didik belum melakukan usaha yang maksimal untuk meningkatkan kemapuan mereka karena mereka tidak percaya bahwa mereka memiliki kemampuan untuk menyelesaikan tugas belajar mereka dengan baik. Pemberian motivasi paling banyak berhubungan dengan peserta didik "persepsi kemampuan mereka sendiri untuk belajar atau mencapai tugas belajar adalah self-efficacy, yang didefinisikan oleh para ahli teori pembelajaran sosial sebagai "rasa keyakinan tentang kinerja tugas tertentu"(Lorsbach dan Jinks 1999, 158). Variabel yang berpengaruh pada pendengar "kinerja adalah self-efficacy. Menurut Bandura $(1986,391)$ dan seperti yang didefinisikan dalam teori kognitif sosial, self-efficacy mengacu pada "Penilaian orang atas kemampuan mereka untuk mengatur dan melaksanakan tindakan yang diperlukan untuk mencapai jenis kinerja tertentu ". Perasaan self-efficacy yang dirasakan peserta didik sangat berpengaruh pada cara mereka menyeleleksi kegiatan serta ketekunan mereka dalam menyelesaikan tugas yang diberikan dalam kegiatan mereka (Schunk 1989; Zimmerman, Bandura, dan MartinexPons 1992). Dengan kata lain, kepercayaan akan kemampuan diri sendiri dapat memprediksi keberhasilan seseorang dalam kemampuan aktual, keterampilan, atau pengetahuan (Schunk 1991). Artinya, "persepsi diri tentang kemampuan membantu menentukan apa yang dilakukan individu dengan pengetahuan dan keterampilan yang mereka miliki "(Pajares 1997, 3). Salah satu teknik yang memberi peserta didik kemampuan untuk belajar bahasa adalah dengan selalu mengulang-ulangi apa yang sudah dipelajari. Shadowing memungkinkan peserta didik untuk tidak hanya mengulang tapi terlibat dalam pengulangan, sebuah proses yang sangat penting untuk pembelajaran bahasa jika dilihat dari sebuah teori sosial kognitif Vygotskyan (SCT): "Dalam perkembangan anak ... imitasi dan instruksi memainkan peran utama "(Vygotsky 1986, 188). Alihalih melihat imitasi secara otomatis, penyalinan mekanis atau pengulangan perilaku model, SCT memahami tiruan sebagai aktivitas transformatif yang melibatkan pelajar yang cerdas, disengaja, dan kreatif menghasilkan operasi mental orang lain (Vygotsky 1986). Dalam teori Vygotskyan, imitasi merupakan mekanisme utama internalisasi dan komponen utama aktivitas perkembangan di ZPD.

Namun, bagaimana ide ini bisa terwujud dalam kelas bahasa dan bagaimana kaitannya variabel kognitif dan afektif masih perlu penelitian lebih lanjut. Dalam penelitian teknik ini digunakan untuk menemukan tentang bagaimana hal itu dapat meningkatkan pemahaman peserta didik di poltekbang Surabaya. Lebih penting lagi, sebuah upaya dilakukan untuk menentukan bagaimana hal itu berkaitan dengan penggunaan strategi metakognitif dan "self-efficacy peserta didik. Secara khusus, pertanyaan berikut ini ditujukan pada penelitian ini.

1) Apakah strategi shadowing pada peserta didik poltekbang Surabaya memiliki pengaruh yang signifikan secara statistik terhadap pemahaman listening mereka?

2) Adakah hubungan yang signifikan secara statistik antara strategi shadowing dan self-efficacy pada peserta didik poltekbang Surabaya?

3) Apakah ada perubahan signifikan pada kemampuan listening metakognitif setelah strategi shadowing diterapkan pada pelajar poltekbang surabaya?

\section{METODE}

\section{Peserta}

Untuk keperluan penelitian ini, 43 peserta didik dengan rentang usia 19-23 tahun, yang mempunyai kemampuan bahasa yang menengah. Mereka dibagi menurut kelas meraka menjadi dua kelompok eksperimen $(n=21)$ dan kontrol $(n=22)$. Peserta dipilih melalui metode convenience sampling. Untuk tujuan ini kelas yang diambil di poltekbang Surabaya adalah kelas ATC 8b dan 8b dengan tingkat kemahiran bahasa ditentukan melalui tesawal penempatan di awal masuk semester.

\section{Instrumen}

Untuk mengukur variabel penelitian (termasuk mendengarkan pemahaman, mendengarkan penggunaan strategi self-efficacy dan metacognitive listening), instrumen berikut digunakan.

\section{TOEIC}

Listening section of the TOEIC digunakan dalam penelitian ini. Instrumen ini merupakan test yang digunakan secara umum. Hal ini menguji kemampuan pebelajar untuk memahami percakapan 
pendek dan percakapan panjang dalam bahasa Inggris. Test ini berisi materi rekaman yang sering didengar sehari hari, lalu pebelajar mengisi form jawaban yang telah disediakan dengan output score TOEIC. Soal tes yang akan digunakan adalah soal tes pilihan ganda sebanyak 100 soal yang berdasarkan soal TOEIC bagian listening oxford university press 2011 practice test 1 untuk pre-test dan practice test 2 untuk post test.

\section{Kuesioner Strategi Mendengarkan Metakognitif (MALQ)}

Untuk keperluan penelitian ini, Metacognition Awareness Listening Questionnaire

(MALQ), yang dikembangkan oleh Vandergrift dan lainnya (2006), diberikan kepada kelompok eksperimen baik di awal maupun di akhir penelitian sehingga memungkinkan adanya perubahan dalam penggunaan strategi tersebut dapat ditentukan melalui perbandingan. Untuk memastikan peserta didik paham maka sebuah versi bahasa Indonesia digunakan dalam penelitian ini. Dalam sebuah penelitian awal, versi ini dikoreksi untuk memastikan tidak akan ada masalah tentang kejelasan. Kuesioner skor yang didapat siswa dipandang sebagai hasil kesadaran listening metakognitif mereka terhadap proses dan strategi yang dibutuhkan untuk mendengarkan bahasa kedua dengan sukses. Kuesioner berisi 21 item, masing-masing item dinilai pada skala Likert enam titik dari 1 (sangat tidak setuju) sampai 6 (sangat setuju) tanpa titik netral sehingga responden tidak bisa menghindar untuk tidak mengisi kuesioner MALQ terdiri dari lima kategori termasuk pemecahan masalah (6 item), perencanaan dan evaluasi (5 item), terjemahan mental (4 item), pengetahuan orang (3 item) dan diarahkan perhatian (4 item).

Validitas kuesioner telah dieksplorasi oleh para pengembang dengan menggunakan eksplorasi dan analisis konfirmatori oleh sampel besar pelajar bahasa asing yang berbeda (Vandergrift, et al 2006).

\section{Mendengarkan Kuesioner Self-Efficacy}

Keyakinan self-efficacy peserta didik dalam mendengarkan diselidiki menggunakan versi bahasa indonesia dari kuesioner self-efficacy yang didengar versi bahasa Inggris (ELSEQ) yang dikembangkan oleh Renzhi (2012). ELSEQ menilai seberapa yakin peserta didik saat melakukan tugas mendengarkan. ELSEQ memiliki 16 item dan masing-masing item diberi nilai pada skala Likert 10 poin mulai dari 0 (tidak yakin) sampai 5 (cukup yakin) dan 10 (benar-benar yakin). Sekali lagi, kuesioner ini adalah pilot- studi yang ditujukan untuk menghindari kemungkinan masalah kejelasan selama pengambilan data melalui kuesioner. Skala koefisien reliabilitas dari kuesioner itu ditemukan .81. Koefisien reliabilitas dari subbagian masing-masing ditemukan $0,78,0,83,0,79$, dan 0,86.

\section{Prosedur}

Tujuan dari penelitian ini adalah untuk mengidentifikasi peran meniruan dari suatu perspektif yang disebut dengan aktivitas listening shadowing dalam konteks EFL. Untuk tujuan ini, kelompok percobaan (EG) diberikan strategi shadowing pada bagian kelas listening mereka; Artinya, setiap kali mereka listening, mereka diminta untuk mengulang dan meniru chunk oleh chunk apa yang mereka telah mendengarkan. Periode pembelajaran mengambil 12 sesi dalam rentang waktu empat minggu. Namun, pembelajaran pada kelompok kontrol (CG) tidak menggunakan strategi tertentu. Uji prestasi mendengar dan juga kuesioner self-efficacy diberikan kepada peserta setelah intervensi sementara MALQ diberikan keduanya sebelum pembelajaran dan sesudahnya sehingga pola potensi perubahan pada peserta penggunaan strategi bisa dilihat.

\section{HASIL PENELITIAN}

Untuk menjawab pertanyaan pertama penelitian, uji $t$ sampel independen digunakan untuk membandingkan pemahaman keterampilan mendengar peserta didik CG dan EG baik sebelum dan setelah pembelajaran. Menjawab pertanyaan penelitian kedua, korelasi pearson digunakan untuk menemukan hubungan antara nilai posttest dari EG peserta didik dan self-efficacy pasca percobaan. Akhirnya uji independent-sample $t$ test digunakan lagi untuk mengetahui perbandingkan dengan menggunakan skor peserta didik CG dan EG sebelum dan sesudah pembelajaran, dan dengan demikian dapat menjawab pertanyaan ketiga dari penelitian ini.

\section{Membandingkan nilai prestasi peserta didik EG dan CG}


Pertanyaan penelitian pertama dari penelitian ini berkaitan dengan apakah strategi shadowing mempunyai efek statistik yang signifikan terhadap prestasi pelajar poltekbang Surabaya. Prestas skor peserta didik pada kedua kelompok, diperoleh setelah melalui bagian listening TOEIC dari oxford, sebelum dan sesudah intervensi disajikan pada Tabel 1.

Tabel 1 Hasil skor prestasi EG dan CG

Table 1 Results of achievement scores of EG and CG

\begin{tabular}{|c|c|c|c|c|c|c|c|}
\hline & Groups & $\mathrm{N}$ & Mean & SD & $\mathrm{df}$ & $\mathrm{t}$ & $\begin{array}{l}\text { Sig. (2- } \\
\text { tailed) }\end{array}$ \\
\hline \multirow{2}{*}{ Pretest } & $\mathrm{EG}$ & 21 & 12.46 & 1.57 & \multirow{2}{*}{41} & \multirow{2}{*}{.71} & \multirow{2}{*}{.41} \\
\hline & $\mathrm{CG}$ & 22 & 13.02 & 1.94 & & & \\
\hline \multirow{2}{*}{ Posttest } & EG & 21 & 18.38 & 2.19 & \multirow{2}{*}{41} & \multirow{2}{*}{6.75} & \multirow{2}{*}{.00} \\
\hline & $\mathrm{CG}$ & 22 & 15.85 & 1.89 & & & \\
\hline
\end{tabular}

Seperti yang ditunjukkan pada tabel 1, hasil yang diperoleh dari menjalankan independen sampel t-test menunjukkan bahwa perbedaan antara kinerja peserta didik di kelompok eksperimen $(\mathrm{M}$ $=12,46, \mathrm{SD}=1,57)$ dibandingkan dengan kelompok kontrol $(\mathrm{M}=13,02, \mathrm{SD}=1,94)$ sebelum perlakuan tidak signifikan, $\mathrm{t}=0,71, \mathrm{p}=0,41$. Namun, hasil yang didapat dari tes setelah intervensi menggambarkan gambar yang berbeda. Kelompok eksperimen $(\mathrm{M}=18,38, \mathrm{SD}=2,19)$ mengungguli kelompok kontrol $(\mathrm{M}=15.85, \mathrm{SD}=1,89)$ dan perbedaannya ternyata signifikan, $\mathrm{t}=6,75, \mathrm{p}=0,00$.

\section{Hubungan antara pendengar belajar EG dan self-efficacy}

Pertanyaan penelitian yang kedua dari penelitian ini adalah untuk mengungkap apakah ada hubungan yang signifikan secara statistik antara strategi shadowing dan kemampuan peningkatan poltekbang Surabaya tingkat 3 pada pelajar. Untuk tujuan ini, korelasi Pearson diterapkan pada skor listening posttest peserta didik EG dan skor self-efficacy mereka diperoleh melalui kuesioner selfefficacy.Hasil analisis disajikan pada Tabel 2.

Table 2 Correlation between EG learners ${ }^{\text {ee }}$ listening and self-efficacy

\begin{tabular}{ccccc}
\hline & & & Listening & Self-efficacy \\
\hline Listening & Pearson & correlation & 1 & .42 \\
& Sig. & (2-tailed) & & .14 \\
& $\mathrm{~N}$ & & 21 & 21 \\
\hline Self-efficacy & Pearson & correlation & .42 & 1 \\
& Sig. & (2-tailed) & .14 & 21 \\
\hline
\end{tabular}

Korelasi antara strategi shadowing, dioperasionalkan melalui posttest listening skor pelajar EG, dan self-efficacy ditemukan cukup positif $(\mathrm{r}=.42)$.Namun, hubungan positif moderat ini tampaknya tidak signifikan secara statistik $(\mathrm{p}=.14)$.

\section{Membandingkan hasil strategi pembelajaran strategi shadowing pelajar EG dan CG sebelum dan sesudah pembelajaran.}

Pertanyaan penelitian ketiga dari penelitian ini dimaksudkan untuk mengetahui apakah strategi shadowing dapat membawa perubahan signifikan pada pola pelajar poltekbang Surabaya pada penggunaan strategi metakognitif. Untuk menjawab pertanyaan penelitian ini, strategi menggunakan skor kedua kelompok tersebut dibandingkan melalui $t$ tes sampel independen sebelum eksperimen dimulai. Demikian juga, setelah selesainya percobaan, uji coba sampel independen $t$ dilakukan lagi untuk mengetahui kemungkinan perbedaan antara kedua kelompok.Hasil analisis uji $t$ ditunjukkan pada Tabel 3.

Table 3 Strategy use of EG and CG learners before and after the experiment

$\begin{array}{lllllll}\text { Groups } & N & \text { Mean } & S D & d f & t & \begin{array}{c}\text { Sig. (2- } \\ \text { tailed) }\end{array}\end{array}$




\begin{tabular}{cccccccc}
\hline $\begin{array}{c}\text { Pre- } \\
\text { Experiment }\end{array}$ & EG & 21 & 64.92 & 4.21 & 41 & .71 & .44 \\
& CG & 22 & 66.03 & 4.76 & & & \\
\hline $\begin{array}{c}\text { Post- } \\
\text { Experiment }\end{array}$ & EG & 21 & 76.19 & 4.15 & 41 & 4.46 & .00 \\
\hline
\end{tabular}

Tabel 3 Strategi penggunaan peserta didik EG dan CG sebelum dan sesudah percobaan Tabel 3 menggambarkan bahwa sebelum percobaan dimulai, tidak ada perbedaan yang signifikan antara mean strategy menggunakan skor pembelajar EG $(M=64,92, \mathrm{~S}=4,21)$ dan yang peserta didik CG $(M=$ $66,03, \mathrm{SD}=4,76), \mathrm{t}=.71, \mathrm{p}=0,44$. Namun, setelah selesainya Percobaan, strategi peserta didik EG menggunakan skor rata-rata $(M=76,19,4,15)$ ternyata lebih besar dan berbeda secara signifikan dengan peserta didik CG $(M=69,58, \mathrm{SD}=3,82), \mathrm{t}=4,46, \mathrm{p}=0,00$. Singkatnya terungkap bahwa strategi shadowing memiliki dampak yang signifikan secara statistik pada pencapaian pendengar pelajar poltekbang surabaya dan analisis korelasi pearson menunjukkan bahwa ada hubungan positif antara strategi shadowing dan kemampuan self-efficacy peserta didik poltekbang Surabaya meskipun hubungan ini gagal mencapai signifikansi statistik. Akhirnya disimpulkan bahwa strategi shadowing ternyata berpengaruh secara signifikan terhadap frekuensi penggunaan strategi metakognitif pada peserta poltekbang Surabaya.

\section{DISKUSI}

Seperti yang ditetapkan pada awal penelitian, tujuan dari penelitian ini adalah untuk menguji hubungan antara strategi shadowing sebagai teknik mengajar dan pelajar poltekbang surabaya pelajaran pemahaman mendengarkan serta keefektifan diri mereka dan penggunaan strategi mendengarkan metakognitif mereka. Analisis statistik hasil penelitian menunjukkan bahwa peserta di kelompok eksperimen berhasil mendapatkan skor yang signifikan lebih tinggi pada tes hasil belajar mendengarkan dibandingkan rekan mereka di kelompok kontrol yang menyiratkan bahwa strategi shadowing itu efektif. Alasan dibalik keefektifan strategi shadowing terhadap kemampuan mendengar peserta didik dapat dikaitkan dengan karakteristik unik dari strategi pembelajaran shadowing pada kelas listening. Menurut Tannen (2007), strategi shadowing merespons dorongan manusia dasar untuk meniru dan mengulangi. Murphey $(2001,132)$ juga berpendapat bahwa strategi shadowing adalah "alat rekursi"karena memungkinkan untuk "penggunaan kembali item bahasa yang sama atau serupa, dari pengulangan yang sederhana, perumusan ulang, hingga produksi baru dan penggunaan baru ". Hasil penelitian ini adalah sesuai dengan penelitian sebelumnya. Dalam sebuah studi baru-baru ini, Commander dan M. de Guerrero (2016) menggunakan pembacaan bayangan sebagai teknik pedagogis yang ditujukan untuk teknik membina pemahaman bacaan dan retensi pada bahasa kedua (L2) atau kelas bahasa asing (FL) merupakan adaptasi dari "conversational shadowing," sebuah prosedur yang mengharuskan pendengar untuk mengulangi apa yang dikatakan oleh lawan bicara mereka dalam usaha untuk mengingat isi interaksi sementara juga berlatih dan belajar bahasa target. Sehubungan dengan tujuan penelitian yang kedua, analisis statistik hasil penelitian menunjukkan ke korelasi positif moderat yang tidak signifikan antara bayangan dan self-efficacy. Demikian, Hipotesis nol kedua sebagian ditolak, namun korelasi tersebut tidak signifikan. Hal ini bisa dibenarkan dengan alasan bahwa durasi pengaplikasian strategi shadowing dalam program mendengarkan mempunyai pedoman dan kriteria tampak belum proporsional. Hal ini bisa diatasi dengan standardisasi durasi lebih panjang Namun, jika variasi ini ditangani secara memadai, memang perlu ada beberapa spesifikasi durasi, misalnya, jumlah jam minimum untuk mendengarkan. Alasan lain bisa dikaitkan dengan cara strategi shadowing disajikan dan diperankan oleh pengajar. Penerapan teknik yang tepat membutuhkan guru yang terlatih dan juga sadar akan penggunaan teknik yang benar.

Studi serupa juga dilakukan oleh Montebon (2016) penelitian ini bertujuan untuk menyelidiki efek strategi pembelajaran shadowing pada siswa yang mempunyai self-efficacy. Strategi shadowing atau tutoring meniru yaitu bentuk utama dari pembelajaran self-efficacy adalah penilaian kemampuan pribadi seseorang untuk merencanakan dan melaksanakan suatu tindakan untuk mencapai suatu tujuan tertentu (Bandura 1977). Hasil penelitian ini menggambarkan latar belakang pendidikan responden dan level keberhasilan self-efficacy. Telah diketahui bahwa siswa yang mempunyai self-efficacy karena pembelajaran strategi shadowing Meninjau penelitian tentang self-efficacy mendengarkan dan 
strategi shadowing, Hamada (2016) menyimpulkan bahwa strategi shadowing mendorong peserta didik untuk mempunyai self-efficacy. Akhirnya, hasil analisis statistik menemukan bahwa penerapan strategi shadowing menyebabkan perubahan yang signifikan dalam pola peserta didik dilihat dari penggunaan strategi metakognitif. Dengan kata lain peserta didik yang menggunakan strategi shadowing dalam pelajaran listening lebih sering menggunakan strategi metakognitif. Ini Jelas bahwa kesadaran metakognitif terhadap strategi mendengarkan mempunyai hubungan dengan pencapaian listening di kelas bahasa Inggris (Kummin dan Rahman 2010), kemampuan mendengar bahasa Inggris (Shirani Bidabadi dan Yamat 2010), dan motivasi belajar bahasa (Baleghizadeh dan Rahimi 2011). Vandergrift, Goh, Mareschal, dan Tafaghodtari (2006) menunjukkan bahwa peserta didik dengan tingkat kesadaran metakognitif yang lebih baik dalam memproses dan menyimpan informasi baru, menemukan cara terbaik untuk berlatih dan memperkuat apa yang telah mereka pelajari. Mengikuti pendapatan ini adalah Coskun (2010) melakukan studi eksperimental pada sampel 40 (pria dan perempuan) pelajar turki tingkat awal belajar untuk mempelajari dampak dari metakognitif selama lima minggu program pelatihan strategi mendengarkan tentang pemahaman mendengarkan. Hasilnya menunjukkan kinerja yang secara signifikan lebih tinggi dimiliki oleh kelompok eksperimen, menyiratkan bahwa pelatihan strategi metakognitif yang diintegrasikan dalam kelas reguler listening untuk mendorong kinerja pendengaran peserta didik. Hamada (2012) juga memasukkan kesadaran shadowing dan kesadaran metakognitif ke dalam pelajaran listening untuk pelajar EFL Jepang dan melaporkan bahwa hasilnya menguntungkan menggunakan strategi shadowing untuk meningkatkan kesadaran peserta didik akan strategi tersebut.

\section{KESIMPULAN}

Para peneliti dan guru untuk berkembang lebih efektif dalam teknik mengajar untuk membantu meningkatkan kemampuan mendengar siswa. Hsil penelitian ini menunjukkan bahwa strategi shadowing cocok untuk kelas reguler poltekbang Surabaya, di mana penekanannya adalah pada pengembangan pemahaman listening. Studi ini juga menunjukkan bagaimana teori teknik mengajar yang efektif, strategi shadowing, bisa digunakan lebih praktis, membangun jembatan antara teori dan praktek temuan penting lain dari penelitian ini adalah dampak positif strategi shadowing pada selfefficacy, dan penggunaan strategi metakognitif pelajar poltekbang Surabaya. Strategi shadowing itu tidak terlalu populer di poltekbang Surabaya dan diharapkan penelitian serupa strategi shadowing akan dilakukan untuk mengembangkan prosedur pembelajaran serupa membantu lebih banyak siswa untuk meningkatkan kemampuan bahasa asing mereka. Temuan dari Penelitian ini dapat memberikan implikasi yang menguntungkan bagi guru dan pembelajar listening. Selain itu, instruktur dapat menggunakan berbagai jenis strategi mendengarkan dan kemudian menerapkan strategi shadowing. Implikasi penelitian ini bisa dipakai untuk pelatihan para guru. Para guru harus terlatih dengan baik mengenai strategi shadowing yang tepat.

\section{DAFTAR PUSTAKA}

Al-Alwan, Ahmed, Sahail Asassfeh, and Yousef Al-Shboul. 2013. "EFL Learners"e Listening Comprehension and Awareness of Metacognitive Strategies: How Are They Related?" International Education Studies, 6(9): 31-39. http://dx.doi.org/10.5539/ies.v6n9p31

Anderson, Neil. J. 1999. Exploring Second Language Reading: Issues and Strategies. Boston: Heinle $\&$ Heinle.

Baleghizadeh, Sasan and Amir Hosein Rahimi. 2011. "The Relationship Among Listening Performance, Metacognitive Strategy Use and Motivation from a SelfDetermination Theory

Perspective." Theory and Practice in Language Studies, 1 (1):61-67. doi:10.4304/tpls.1.1

Bandura, Albert. 1977. "Self-Efficacy: Toward A Unifying Theory of Behavioral

Change. Psychological Review, 84: 191-215. https://www.uky.edu/ eushe2/Bandura/ 